\title{
WOMEN'S ENTREPRENEURSHIP POLICY: A 13 NATION CROSS-COUNTRY COMPARISON
}

\section{INTRODUCTION}

Small business and entrepreneurship policies have played a key role in economic strategy and development since the 1980s, and are considered to be an important component of the entrepreneurial ecosystem (Mazzarol, 2014). For many economies, this includes genderfocused entrepreneurship policies (European Commission, 2004; Mayoux, 2001). To inform policy development, this study draws on gender and institutional theory to examine policy support for women-owned enterprises in 13 countries across five continents. The rationale for the Global WEP research project is evidenced in several ways. First, global economic forums increasingly view gender equality as both a moral and economic imperative (OECD, 2014; APEC, 2004, 2010, 2011). Yet, scholars report gender-biases in SME/entrepreneurship policy frameworks (Alsos, Ljunggren \& Hytti, 2013; Gicheva \& Link, 2015). The majority of entrepreneurship policy studies lack sex- or gender-based analysis ${ }^{1}$ (Orser \& Elliott, 2015), and few gender studies on women's entrepreneurship articulate policy implications (Foss, Henry \& Ahl, 2014). Furthermore, most government-funded studies about women entrepreneurs are atheoretical and/or merely profile exemplary women-focused support services. Few critically examine socio-political and normative factors that influence women's entrepreneurial endeavors. There is an absence of cross-country (evidence-based) policy research about women's entrepreneurship, including the role of political structures in influencing women's enterprise. This includes the impacts of policy on the "...overall position of women in the context of life opportunities and equality" (Ahl \& Nelson, 2014: 273). In response, this study employs 'a gender lens' (Rankin \& Vicker, 2001) to examine SME/entrepreneurship policies targeted at women entrepreneurs. The findings will be of interest to academics and others who seek to shape female-focused SME/entrepreneurship policy.

\footnotetext{
${ }^{1}$ Sex or gender-based analysis “....seeks to capture material, perceptual, and relational changes that result from the introduction of policies and programs. Material changes reflect economic security and access and control of other resources such as health, childcare, nutrition, and housing. Perceptual changes imply self-confidence, vision, and understanding one's individuality and capabilities. Relational changes capture the role of women in the household, local and national communities, and the ability to act independently (that is, reduce one's independence on intermediation by others)." (Orser \& Elliott, 2015: 154).
} 
Second, there remains considerable debate with respect to the need for gender-focused versus gender-mainstream policy (Mason \& Brown, 2014), and the ways in which market interventions affect the entrepreneurial experiences of men and women (Stevenson, 2004). ${ }^{2}$ As Hart (2003: 16) asserts “... where public policy and governance can and do shape entrepreneurial behavior we ought to be conscious of their consequences and improve them to the extent possible." A starting point is to catalogue the incidence and construction of female-focused SME/entrepreneurship policies, including the assumed beneficiaries (e.g., assumption of homogeneity versus inclusion of marginalized communities, such as immigrants, disabled, LBT, low income and Indigenous women).

Third, at the macro-level, socio-political and cultural influences account for variance in entrepreneurial activity (Griffiths, Gundry \& Kickul, 2013; Minniti \& Nardone, 2007). However, it is not clear the extent to which these institutional factors are implicitly or explicitly addressed in women's SME/entrepreneurship policy. It is also assumed that female-focused SME/entrepreneurship policies have the potential to enhance the entrepreneurial ecosystem for women by confronting gender-related barriers to firm start-up and growth. Cross-cultural studies are needed to examine the degree to which institutional remedies are employed in policy (Ahl \& Nelson, 2015). In response, this study seeks to address the research question: How - and to what extent - do women's entrepreneurship policies differ among countries?

To inform our research question, the next section presents an overview of the gender barriers faced by women entrepreneurs. A discussion on the state of women's entrepreneurship policies follows. An institutional approach to examining country-level entrepreneurship policy data is described. The common approach methodology used to map cross-country SME/entrepreneurship policies is then presented, and this is followed by a presentation of the study findings. The paper closes with conclusions and implications for future research.

\section{LITERATURE REVIEW}

\section{Gender Barriers Faced by Women Entrepreneurs}

Over the years, a number of scholars have pointed out that women and men entrepreneurs are similar in many respects (Birley, 1989; Du Reitz \& Henrekson, 2000; Kepler \& Shane, 2007). Others contend that there are distinct gender differences and that these differences have a 
profound effect on the ways in which men and women approach and practice entrepreneurship. Differences are typically grouped into five categories that include education, experience, networks, access to capital, and context. Consistent with resourcebased theory (Brush et al., 2001b; Hanlon \& Saunders, 2007; Sirmon \& Hitt, 2003), the first four categories constitute key inputs for the entrepreneur. Education and experience are elements of human capital, while networks are a reflection of the entrepreneur's social capital. Research has documented the importance of human and social capital in the launch, survival, profitability, and growth of entrepreneurial ventures (Brush et al., 2002; Coleman, 2007; Cooper et al., 1994; Garcia \& Carter, 2009). Similarly, financial capital is identified as a key input, particularly for entrepreneurs who aspire to grow their firms (Brush et al., 2001a; Ibid, 2004; Coleman \& Robb, 2016). The fifth category, context, is relevant in that it informs about motives, attitudes and goals of entrepreneurs (Coleman \& Robb, 2012).

With respect to resource acquisition, a growing body of research suggests that structural and attitudinal impediments make it relatively more difficult for women to secure needed resources in the areas of human, social and financial capital compared to men. These impediments, in turn, tend to influence opportunity recognition, the types of firms that women launch and the subsequent success of those firms. For example, in terms of education (human capital), it is noted that women are significantly less likely to pursue degrees in the STEM (science, technology, engineering, math) fields. These academic disciplines often serve as a birthplace for entrepreneurial ventures, particularly those in the fields of technology and bioscience (Coleman \& Robb, 2012). Research also suggests that when women do pursue careers in these fields, they encounter male-dominated cultures and hierarchies that are unwelcoming (Marlow \& McAdam, 2013; Ranga \& Etzkowitz, 2010). These factors contribute to industry segregation, with women tending to launch firms in highly competitive and less profitable sectors, such as retail and personal services.

From an experiential perspective, many women encounter impediments to advancing their careers (garnering human capital). ${ }^{2}$ A number of researchers have addressed the fact that

\footnotetext{
${ }^{2}$ As an example, although the majority of American women work outside of the home, few have reached senior ranks of corporations (Women in the Labor Force, 2015). Catalyst Group reveals that $4 \%$ percent of Fortune 500 companies are headed by female CEOs, and that women hold 19\% of Board Directorships (Catalyst, 2016). The 2015 Global Women Entrepreneur Leaders Scorecard also reports that women who are precluded from reaching the senior ranks of major corporations, are precluded from developing the strategic and decision-making skills that help to launch and grow firms.
} 
women's entrepreneurial networks (social capital) are different from those of men (Aldrich, 1989; Aldrich et al., 1989). This can serve as a structural barrier in that women may not be a part of networks that provide access to information, referrals, resources, and contacts. The Diana Project, for example, has focused extensively on networks as a significant genderrelated impediment to accessing financial capital, noting that the majority of venture capitalists are males who are inclined to invest in firms led by men (Brush et al., 2001a; Ibid., 2004, Gatewood et al., 2009). Scholars have reported similar observations regarding the composition of angel networks, and the availability of equity capital (Becker-Blease \& Sohl, 2007; Harrison \& Mason, 2007). Gender-based differences in networks pave the way for gender differences in financial capital.

Research reveals that women launch firms with significantly smaller amounts of financial capital than men, across all industries and firm types (Coleman \& Robb, 2009; Ibid, 2016). Within the various categories of financial capital, women are heavily reliant on internal rather than external sources of financial capital. This represents a challenge in that women, on average, have lower earnings and accumulated wealth than men (Arulampalam et al., 2007; Blau \& Kahn, 2007; Piacentini, 2013). Similarly, women are more likely to work part-time and experience career interruptions associated with domestic responsibilities (Closing the Gender Gap: Act Now, 2012).

Studies reveal that women entrepreneurs employ significantly lower amounts of external equity capital than men during the early and later stages of their firms' development (Coleman \& Robb, 2016). Although previous research suggested that women have gained better access to external debt (Haynes \& Haynes, 1999), the same cannot be said for their access to external equity via angel and venture capital (Brush et al., 2004; Coleman \& Robb, 2009). This poses a significant barrier for women attempting to launch growth-oriented firms and a threat to the continued survival of those who have already done so.

The fifth category focuses on the effect of context and its role in shaping entrepreneurial motivations, attitudes, and goals. Scholars observe that women often operate within different contexts than men (Ahl, 2006; Brush et al., 2009). Although the majority of women work outside the home, as noted, women continue to have primary responsibility for care of the home, children, and other family members (Piacentini, 2013). Thus, women may have less time to devote to entrepreneurial ventures, particularly when children are young. Different 
circumstances, therefore, affect decisions to launch lifestyle rather than growth-oriented entrepreneurial firms as a strategy for balancing work and family demands (Cliff, 1998; Coleman \& Robb, 2012).

This overview describes several of the ways in which structural and attitudinal barriers impede women's entrepreneurial progress relative to men. Collectively, gender-based impediments are seen to effect the decision to launch an entrepreneurial firm, sector choice, time invested, capitalization and ultimately, firm survival and longevity. In response, The World Bank Group (2014) writes that to induce female entrepreneurs to diversify into higher value-added activities: (a) experimentation in the design and delivery of small business support services, and (b) a focus on strengthening the engendering of small business programs to address gender-specific constraints are needed. Specifically, policy must deal with social norms, entrepreneurial preferences, institutional arrangements, and changing public discourse. This summary lays the groundwork for the discussion on the state of entrepreneurship policy to address gender barriers faced by women entrepreneurs.

\section{State of women's entrepreneurship policy}

Several studies have examined the state of women's entrepreneurship policy (see Global Women Entrepreneur Leaders Scorecard, 2015; Kvidal \& Ljunnggren, 2014; Lundstrom \& Stevenson, 2007; Stam, 2015; Welter \& Smallbone, 2011). Scholars have also: reported on the types of gender-focused entrepreneurship policies (Mayoux, 2001; Orser \& Riding, 2006); modelled gender effects on the start-up decision, independent of country-specific circumstances (Minniti \& Nardone, 2007); and described the provision of women's entrepreneurship policies in specific countries (for example, in Poland, see Zapalska, 1997; in the UK and US, see Marlow, Carter \& Shaw, 2008; in Canada, see Orser, 2014). National task forces have sought to inform policymakers about the state of women's entrepreneurship and the need for gender-focused policy interventions. By way of specific examples, we refer readers to the Canadian Taskforce for Women's Business Growth (Orser, 2011); EU Evaluation on Policy: Promotion of Women innovators and Entrepreneurship, 2008; UK 
Enterprise Strategy, HM Treasury and BERR, 2008, 2009; OECD, 2014; Women's Enterprise Scotland, $2015 .^{3}$

A review of the above task force report conclusions and recommendations finds that: women's entrepreneurship policies focus primarily on individual-level challenges ('do-ityourself solutions') rather than institutional (cultural and normative) level interventions; ${ }^{4}$ gender disaggregated data are lacking with respect to access and utilization of small business support services (e.g., incubators, start-up garages, technology transfer facilities); few countries integrate women's entrepreneurship policies across key economic ministries; policymaking about women's entrepreneurship is located outside the core economic policy process; and women's entrepreneurship policies are ghettoized in agencies tasked with women's safety and social welfare. Policies for women's entrepreneurship are routinely evaluated for design and effectiveness, but not for impact on the position of women with respect to equality or 'life opportunities' (Ahl \& Nelson, 2014). Cross-cultural research also suggests that entrepreneurship policy is gendered, and that policies further subordinate women's entrepreneurship to neo-liberal goals, such as job creation and economic growth (the business case for policy intervention) rather than gender equity (Ahl and Nelson, 2014).

In a study that compared how the Swedish and US government position women entrepreneurs in policy documents, Ahl and Nelson (2014: 285) identify several common discourses about women's entrepreneurship. These include: "Women entrepreneurs are an under-utilized resource in terms of national economic growth goals"; "Women entrepreneurs face discrimination on the basis of sex"; "Women entrepreneurs are (are not) different from men, for better or worse"; Women entrepreneurs are just like 'other' entrepreneurs"; "Building women's entrepreneurship is women's work"; "There is reason for optimism and reason to persevere: the dream of equality is possible"; and "Entrepreneurship may lead to gender equality, but as a secondary effect as it supports other goals". Discourse is viewed as positioning women entrepreneurs as "other," thereby reinforcing women's inadequacy. Given the US is identified as a 'best practice' nation with respect to business services and policy

\footnotetext{
${ }^{3}$ Gender explicit indices have also been introduced to monitor women's entrepreneurship. For example, see The Economist, 2012; Global Women Entrepreneur Leaders Scorecard, 2015; and The Global Entrepreneurship and Development Institute, Female Entrepreneurship Index, 2015.

${ }^{4}$ Documented gender-related barriers reflect firm-level challenges, such as limited access to capital, access to markets, utilization of technology, and the need for capacity and skills building. Industry-level barriers include lack of role models, absence of proactive approaches to increase the representation of women in leadership roles and lack of gender-disaggregated data (APEC, 2011).
} 
support for women's entrepreneurship (Global Women Entrepreneur Leaders Scorecard, 2015), the study observations are concerning. The next section highlights factors associated with women's entrepreneurial engagement to explain the theoretical approach employed in the study.

\section{Theoretical Approach to Analysing Women's Entrepreneurship Policy ${ }^{5}$}

The objectives of most entrepreneurship policies are to increase the ease of doing business (e.g., by dismantling legal and legislative barriers), and to facilitate access to resources requisite to start-up and firm growth (Acs \& Virgill, 2011). ${ }^{6}$ Common interventions include access to financing, government policies, taxes and bureaucracy, government programs, school-level entrepreneurship education and training, post-school entrepreneurship education and training, $\mathrm{R} \& \mathrm{D}$ transfer, access to commercial and professional infrastructure, internal market dynamics, internal market burdens, access to infrastructure, and social and cultural norms (Global Entrepreneurship Monitor - GEM, 2015). GEM 2015 also reports that there are significant differences in policy support across the entrepreneurial ecosystems of the 60 economies surveyed. Innovation-driven economies were deemed to be strongest with respect to government support. ${ }^{7}$ Interestingly, only one criteria - cultural and social norms (defined earlier as 'context') - rated highly across countries situated within three phases of economic development (factor-driven, efficiency-driven and innovation-driven economies). Again, the 10 most highly-rated economies were innovation-driven. This latter finding is important,

\footnotetext{
${ }^{5}$ Lundstrom and Stevenson (2002: 10) were among the first to differentiate and categorize small business and entrepreneurship policies: where, small business policy pertains to SMEs as 'entities' whereas entrepreneurship policy is "...oriented more towards individuals and individual behaviour." Examining the impacts of SME/entrepreneurship policy, Lundstrom and Stevenson (2002) conclude that good practice focuses on the centrality of the founder/owner, given that "...it is individuals who create new businesses and develop existing ones."

${ }^{6}$ For example, in examining policies associated with the US transition from managerial to entrepreneurial capitalism, Acs and Szerb (2007) cite the removal of legal and bureaucratic hurdles to business start-up; requirement for cost/benefit assessment of new federal regulation; availability of pension funds to finance startups; provision of R\&D tax credits; and university control and commercialization of inventions.

${ }^{7}$ Leaders in the entrepreneurial eco-system included Switzerland, the Netherlands, Malaysia, Canada and Luxembourg. GEM employs the World Economic Forum (WEF) three-point classification of economic status. Factor-driven economies are described as "...dominated by subsistence agriculture and extraction businesses, with a heavy reliance on (unskilled) labor and natural resources. In the efficiency-driven phase, an economy has become more competitive with further development accompanied by industrialization and an increased reliance on economies of scale, with capital-intensive large organizations more dominant. As development advances into the innovation-driven phase, businesses are more knowledge-intensive, and the service sector expands. http:// weforum.org (GEM, 2015: 11).
} 
given GEM (2014) reports an association between cultural and social norms and the propensity of females to engage in entrepreneurial activity. Even within innovation-driven economies, policies that fail to address gender biases in cultural and social norms compromise the engagement of women in entrepreneurial activity. Gender equality is, therefore, deemed a significant social and cultural determinant of entrepreneurial activity. As Griffiths et al. (2013: 350) write:

“...in cultures where female entrepreneurship is perceived to have lower legitimacy in comparison with male entrepreneurship, women's self-perceptions and attitudes can affect their likelihood of pursuing this career choice, and this constrain women-led new ventures (Achtenhagen \& Welter, 2003). In contrast, countries that provide normative support for women entrepreneurs, exhibiting admiration and respect along with gender equality, are likely to observe a higher level of female entrepreneurship activities (Baughan et al., 2006)."

Given the impact of macro-level policies, social norms, and culture on stimulating and supporting women's entrepreneurial activity, an 'institutional approach' to examining government policy is advanced (Foss \& Gibson, 2015; Tolbert et al., 2011; Welter \& Smallbone, 2011). As such, we draw on Scott's (2014) framework that identifies regulative, normative and cognitive forces that shape and constrain women's entrepreneurship, in the different country contexts. Applying Scott's (2014) institutional framework strengthens the understanding about how women's entrepreneurship policies differ across countries, the extent of such differences, and whether policies are likely to shape or constrain women's entrepreneurial development; improving or impairing entrepreneurial ecosystems.

The framework incorporates three pillars:

- The regulative pillar contains mandated specifications including laws, governance and monitoring systems. This pillar is derived from a rational economic model of behavior (North, 1994) concerning rules, sanctions and conformity. ${ }^{8}$ Specifically, this study seeks

\footnotetext{
${ }^{8}$ This pillar incorporates the notion of 'state feminism' defined as the degree to which women activists (women's enterprise councils, networks, and associations) access or influence government decision-making. "...The concept refers to the "activities of government structures that are formally charged with furthering women's status and rights" (Stetson \& Mazur, 1995: 1-2). The evolution of state feminism is important in determining whether the network of status-of-women machinery that exists within state structures provides opportunities for women to achieve change or if it exists mainly by to let governments say they are consulting women and taking their needs into account." (Rankin \& Vickers, 2001: 6)
} 
to understand how regulatory policies and rules encourage and/or discourage women's entrepreneurship.

- The normative pillar concerns values, expectations and standards, such as roles, repertoire of action and conventions. This pillar underlies understanding motivation for, or resistance to, entrepreneurial behavior within different country contexts.

- The cultural-cognitive pillar denotes predispositions and symbolic value as a model for individual behavior regarding the individual acceptance of entrepreneurship.

The review of literature suggests that examination of public policies that seek to address gender barriers for women entrepreneurs must consider factors that shape women's work experience, including government laws, governance, regulatory and monitoring mechanisms - the focus of this study. In the next section, the common methodological approach employed by the Global WEP team to analyze sample documents of the 13 countries is described.

\section{METHODOLOGY}

This paper presents findings of the Global Women's Entrepreneurship Policy (Global WEP) Research Project. The project objectives are to map and critically compare public policies for women's entrepreneurship, to identify gaps in policy provision, and to highlight examples of good practice policies that support women's entrepreneurship. The Global WEP concept was launched at the Diana International Research Symposium (Stockholm, June 2014), where expressions of interest were sought from the research community. Expressions of interest were received from 15 country teams, 13 of which have contributed data to this paper: Australia, Canada, Germany, Ireland, New Zealand, Northern Ireland, Norway, Pakistan, Spain, Sweden, Tanzania, UK and the USA.

Phase I of the project involved secondary research: critically exploring extant policy documents underpinning entrepreneurship policy discourses in each of the sample countries. The core research question examined in this paper is: How - and to what extent - do women's entrepreneurship policies differ among countries? Following Henry, Foss \& Ahl (2016), a common reading guide was designed (see Table 1). The guide enabled the researchers to examine policy texts according to type, author gender, focus/themes, imagery and language, recommendations, key contributions, and level of policy relevance to women's entrepreneurship. 
Phase II will involve a schedule of empirical work relating to the prevailing policy environment - the broader entrepreneurial ecosystem - and the specific policy initiatives 'on the ground' in each partner country. To inform this phase of the study, the Global WEP teams were also asked to identify (where available) examples of women-focused entrepreneurship policy and programs initiatives ('on the ground') in their respective economies. These will be examined in greater detail in Phase II of the project. This empirical work will comprise a series of interviews with policymakers and/or government representatives and informed commentators, as well as a selection of case studies for the purposes of identifying gaps in current policy provision and highlighting good practice.

\section{Analysis}

A qualitative, discursive approach was adopted. In October 2015, members of the research team attended a workshop to review the study methodology, present preliminary countrylevel findings, and discuss potential challenges (Dundalk, Ireland). A lack of and/or limited access to entrepreneurship policy documents, the currency of existing policy statements, and differences in how team members interpreted the term 'policy document' were identified as issues. To align cross-country data and to improve reporting consistency, each team then reviewed their respective data with the objective of revisiting the selected 'policy' documents. It was agreed that, in the absence of a core/official policy document (as described in point 2 below), teams would identify the next 'best match' and, if necessary, offer proxy texts (if required). Policy documents were coded as: (1) academic articles (i.e. journal articles, book chapters, conference papers, etc.); (2) policy documents (i.e. official policy documents, policy statements, policy strategies issued by standing government); (3) policy studies/reports (i.e. documents produced by contracted organizations, researchers, or other bodies, evaluating extant policies and/or identifying gaps in current policies); and (4) small business/entrepreneurship programs or related initiatives (i.e. support projects/programs on the ground, perhaps set up on behalf of government or their agents).

Three documents were selected for each country by the respective research team, except for Tanzania where two documents were selected. This was due simply to a lack of relevant policy-related (or suitable proxy) documentation. To facilitate analysis, data from the country-level reading guides were compiled into a single 'master' excel spreadsheet. This 
enabled comparative content analysis, identification of key observables, and descriptive critique of the document narratives. The following section presents the findings.

\section{FINDINGS}

\section{Document analysis}

Thirty-eight documents, representing 13 countries across five continents (Africa, Asia, Australasia, Europe and North America) were received. Table 2 provides a profile of the data. Table 3 provides a summary of key observables. Of the 38 documents, 20 described general entrepreneurship/business, where women may or may not have been mentioned; 18 documents explicitly described women entrepreneurs (female-focused, as determined by the document title). ${ }^{9}$

\section{Document type and authorship}

All but one document were core policy texts issued/sponsored/contracted by government or one of its agencies (Category 2). By exception, one Canadian document was categorized as "a gap report/policy recommendations document authored by other organizations (Category 3). Where identifiable, author teams were primarily mixed gender (Australia, Canada, Northern Ireland, Norway, Sweden, UK and USA); of these, two were equally-balanced male/female teams (Australia and Northern Ireland); three were male-dominated (UK, Norway and USA); and two were female-dominated teams (Canada and Sweden). Three documents were authored by all-female teams (Canada, Northern Ireland and USA); two were authored by all-male teams (Pakistan). It is notable that among the 38 documents examined, 26 were anonymous (i.e. authorship unknown). Only one government department was cited as the author.

\section{Imagery}

Most imagery was deemed to be generic/neutral - or, in several cases, 'politically correct' or 'civil service style.' Neutral graphics took the form of maps, business-like pictures (such as computers), and national symbols. Some images were interpreted as 'gendered', through the representation of predominately male sectors (such as, engineering and science graphs, charts, a bridge). Despite focusing on general entrepreneurship/business (rather than women-

\footnotetext{
${ }^{9}$ Equality policy documents in which women are given special mention in the context of entrepreneurship are included in this figure.
} 
focused), document covers and body text used predominately male imagery (e.g., one Norwegian document profiled a young man on the cover).

Among the 18 female-focused policy texts, imagery was primarily in the form of photographs of single females (for example, Norway and New Zealand) or group composites of females (USA). One country (Canada) profiled a mixed gender composite. Some of the images depicted women in business attire (for example, USA). The dominant image of a New Zealand document was that of craft, low tech and micro business; one Swedish document showed photos of women in different roles, some of them gendered.

\section{Language}

With the exception of two general entrepreneurship/business text documents (New Zealand and Pakistan), language was deemed neutral/generic. Several employed 'uplifting' linguistics (aspirational, ambitious, for example, see Ireland, New Zealand and Pakistan). Among the 18 women-focused policy texts, five used gendered language (Germany, New Zealand, Northern Ireland, UK and Norway). This reflects the inclusion of case studies of women entrepreneurs and/or women-focused government support initiatives. One document was deemed to be feminist, occasionally criticizing men, and highlighting the stringent gender roles/power relations that present challenges to women (Pakistan). Amongst the women-focused Swedish documents, one was deemed to be 'politically correct' in terms of its language. One UK document mentioned men first in all discussions of male/female differences. The language in one of the USA document was viewed as patronizing to men and women.

\section{Themes}

Policy texts varied in focus, from general considerations to specific themes, sectors and measures to support women entrepreneurs. Resourcing (especially access to finance), growth, internationalization, competitiveness, and innovation were recurring themes. Some documents focused on specific populations (such as youth, rural communities) while others described with specific sector initiatives (such as, support for ICT, STEM, agri-business, creative and/or craft). Some detailed barriers and challenges facing women entrepreneurs. German and Norwegian documents present good examples of detailed policy initiatives focusing on an explicit range of issues. Irish and Norwegian documents were amongst the few to focus on improving the broader ecosystem for entrepreneurs - including women - 
highlighting the need to have the right conditions for entrepreneurship (for example, streamlining rules, regulations and bureaucracy).

\section{Relevance to women's entrepreneurship}

In terms of level of relevance to women's entrepreneurship policy, less than half $(n=17)$ were deemed to be highly relevant; $18 \%$ were deemed to be of medium relevance; $16 \%$ were categorized as low level of relevance; and the remainder had no relevance. For example, all Canadian, German, Swedish and American texts were deemed to be highly relevant to women's entrepreneurship policy. Most documents from Australia, Ireland and New Zealand were deemed to have low or no relevance.

Across the documents, the main contributions to women's entrepreneurship policy were: (a) affirmation of research highlighting gender differences; (b) gender-related challenges confronting women entrepreneurs; and/or (c) need for dedicated entrepreneurship policy support for women. For example, some profiled the challenges faced by women entrepreneurs, or drew attention to male-female differences in terms of entrepreneurial characteristics and behaviors (e.g., attitude to risk, motivation, growth orientation, access to capital). Some documents focused on differences in sector representation (such as, STEM, health, education or the informal sector). The Canadian research team indicated the documents expanded the policy conversation from firm to owner level and, more specifically, prompted subsequent women-focused initiatives, such as female trade missions. Two Norwegians documents contributed to women's entrepreneurship in terms of enhancing welfare rights and by focusing on young women and women in the health care sector; two Northern Ireland documents contributed to the broader equality agenda and, more specifically, subsequently led to a dedicated women's entrepreneurship initiative. While some documents helped lay the foundation for future female-focused entrepreneurship policy, one research team (USA) felt that too much focus on differences and challenges perpetuated negative myths about women entrepreneurs (e.g., women are not interested in growing their businesses or in achieving financial or economic wealth). This sentiment was partly supported by the Irish team, whose documents contextualized women as under-represented and/or part of a minority group. One women-focused document suggested that there was no need for a women's enterprise policy, because barriers to success for women in enterprise are no different to those of women in employment (New Zealand). 
Some documents were deemed to significantly contribute to women's entrepreneurship policy, as they - for the first time - formalized government recognition of the importance of women's entrepreneurship, acknowledged that women entrepreneurs are an integral part of SME development, articulated commitment to developing and supporting women entrepreneurs, and laid foundations for subsequent policy development (for example, Tanzania). Even in documents that were not specifically focused on women entrepreneurs, there was a sense that when women were formally mentioned, it was a step forward (see, Pakistan).

\section{Policy recommendations}

Policy recommendations were wide-ranging: some documents were more detailed than others. General recommendations included educating the next generation in terms of financial literacy, increasing research and improving evaluation, looking at good practice in other countries, and improving co-ordination between existing policies and agencies.

Among the documents that focused explicitly on women entrepreneurs, the dominant recommendation pertained to increasing soft supports, such as role models, international networks and mentoring. Several recommended improving access to capital. Norwegian documents recommended providing entrepreneurs the same access to welfare benefits as waged earners and improving maternity and parental benefits. Tanzania recommended empowering the youth. Germany, UK, Ireland and the USA were amongst those economies with relatively detailed recommendations; one of the USA documents offered 23 recommendations relating to STEM, childcare, and access to equity capital from venture capitalists and angel investors. Several countries focused recommendations on specific sectors. Two documents focused on supporting engagement in STEM - one (UK) suggesting a need to provide female (STEM) students with female faculty mentors (presumably to enhance publication and subsequently commercialization potential), and one (Australia) encouraging more girls and boys to engage with STEM disciplines.

\section{Policy initiatives and programs 'on the ground'}

Table 4 presents a preliminary analysis of initiatives, grouped into the five categories of gender barriers identified in the literature review. As illustrated, most Global WEP sample economies support initiatives/programs that seek to address 'deficits' in women's experiences (in the form of business training), networking and financial initiatives. Most also 
have an institutional focal point for women, in the form of one or more Women's Business Centres. Such initiatives tended to have a broad remit in the area of supporting women's enterprise, and hence could be categorized as addressing barriers relating to both context and experience.

Some networking programs were designed around encouraging innovation, exporting or growth; some were linked to funding opportunities, and others were focused on particular business sectors. For example, in Northern Ireland, the Women in Business NI (WIBNI) network reports over 1,000 members, and offers events aimed at helping women develop personally and professionally as entrepreneurs. WIBNI also offers a variety of free marketing benefits to members, including publication of news articles in a quarterly magazine and in a monthly 'ezine'. Only the Australian, Swedish and Pakistani research teams highlighted initiatives that addressed barriers relating to education. These took the form of financial literacy initiatives in Australia (interestingly, these were not intended to be only women-focused), business ambassador programs in schools (Sweden) and dedicated women's study centers (Pakistan). Germany, Pakistan, Sweden and, to some extent the USA, appeared notably strong on initiatives that addressed contextual barriers, as evidenced by welfare, equality and employment programs and regional support centres. There was a notable lack of women-focused programs in New Zealand, with the Māori Women's Development Inc. (MWDI) being the sole initiative identified by the research team. ${ }^{10}$

\section{DISCUSSION}

This paper highlights findings from the initial phase of the Global Women's Entrepreneurship Policy (WEP) research project. Text-analysis of country-level policy documents found significant differences in support for women entrepreneurs among the 13 economies surveyed. At a fundamental level, some economies formally endorse womenfocused entrepreneurship policies (e.g., Norway, Sweden, Pakistan, USA), while others do not (Ireland, Tanzania). Interestingly, in the case of Ireland, while there was no dedicated women's entrepreneurship policy, there were several women-focused initiatives and programs in operation 'on the ground' that were not captured in the higher level policy

\footnotetext{
${ }^{10}$ Established in 1987, MWDI offers finance and mentoring services with loans between NZ\$ 30,000-50,000. Māori women who wish to start or expand a business - (as well as Māori men who have Māori women as part of their core business operation) - are eligible to apply. The initiative has received ongoing government funding, with some NZ \$1,867000 provided annually; it has been in operation for more than twenty-five years.
} 
documents. In certain instances, entrepreneurship policies were broadly defined and/or aspirational (Ireland), while other policies were targeted and detailed (Germany, Norway and Sweden) and/or prioritized industry sectors (Sweden), international markets (Ireland), competitiveness (UK) and innovation (Australia, Ireland, Norway), growth (Sweden, USA, Northern Ireland), financial literacy/access to capital (Australia, Canada, Tanzania, USA), and/or commercialization of technology/STEM (Australia, USA).

Notable differences were seen in terms of relevance to women's entrepreneurship; their contribution and the extent to which they appeared biased in terms of language and imagery used. Differences were also noted with respect to how women entrepreneurs were positioned within industry sectors and categorized into 'disadvantaged', 'minority' or 'underrepresented' groups. These practices are deemed in extant women's entrepreneurship scholarship to perpetuate subordination of women and related myths of under-performance, deficits and 'other' (Ahl, 2004; Ahl \& Nelson, 2014; Marlow et al., 2008; Henry et al., 2016).

The gender make-up of the respective author teams varied. While not all authors were identified, where women dominated the authorship team, policies were more likely to recognize gendered challenges facing women (for example, highlighting multiple roles women often play in society; see Sweden and the USA). This area of inquiry merits further investigation.

\section{Scott's Institutional Framework}

Regulative pillar

This pillar - as illustrated in Figure 1 - pertains to rules and regulations; structural dimensions of government, and the bureaucracy associated with business set-up and operation. This includes legal, taxation and fiscal aspects of policy formation, including welfare systems. In the study sample, several policies aimed to address the regulative pillar and to contribute to improving the general operating environment for women's entrepreneurship. For example, policies in Spain and Norway proposed changes to welfare and social security payments for self-employed women. German documents highlighted the need to improve the general regulatory business framework. A UK document proposed tax incentives for STEM and ICTrelated commercialization. A Canadian document suggested fiscal measures to encourage investment in high-risk enterprises. Interestingly, while Ireland's documents were not 
women-focused, they prioritized strengthening the general entrepreneurial ecosystem and reducing barriers to venture creation and operation.

\section{Normative pillar}

This dimension concerns values, expectations, standards and conventions. The normative pillar also underpins our understanding of motivation for, or resistance to, entrepreneurial behavior. Considerations include social expectations of women, including family roles and responsibilities. Policies addressing normative aspects were identified in documents from Sweden, Northern Ireland, Australia, Canada and New Zealand. Policies typically highlighted structural barriers associated with women's entrepreneurship. One USA and one UK document focused on encouraging more girls/women into STEM areas. One Northern Ireland document prioritized entrepreneurship amongst youth, hence increasing the future pipeline of entrepreneurs. One Swedish document focused on women entrepreneurs being associated with particular 'gendered' industry sector, and, along with Norway, suggested improvements to the welfare system. One UK document also highlighted the need for child-care facilities and support. Policy documents that most strongly sought to address the normative dimension could be found in Tanzania and Pakistan, where systemic barriers to women's entrepreneurial development appeared to be most problematic.

\section{Cultural-cognitive pillar}

Under this pillar, predispositions and symbolic values are seen to influence behavior regarding the individual acceptance of entrepreneurship. Cognitive aspects included perceived general preparedness for becoming an entrepreneur, education, work experience and business knowledge (entrepreneurial self-efficacy). Most documents sought to address this pillar, with a wide range of recommendations around training, education and business support to enhance entrepreneurial knowledge. Many recommendations were in the form of establishing or continuing support of women's enterprise/business centers. Documents from Australia, Canada and the USA recommended actions to strengthen financial literacy particularly amongst women - highlighting the importance of finance in entrepreneurial endeavors. Policies in Tanzania and Pakistan were strong in this regard, acknowledging that as with the normative dimension -cognitive aspects of entrepreneurship need particular attention in order to change cultures and facilitate more women engaging in entrepreneurship. 


\section{CONCLUSIONS}

This study sought to address the research question: How - and to what extent - do women's entrepreneurship policies differ among countries? Drawing on gender and institutional theory, we report on the analysis of documents gathered from 13 economies across five continents. A common methodological approach was designed to report on the state of women's entrepreneurship policy and to identify gaps in the policy-practice nexus. The paper contributes to extant theory by enhancing understanding of women's entrepreneurship policy at the global level, and by establishing a common methodological approach to cross-country, comparative policy research in this field.

Applying Scott's (2014) framework to our analysis revealed that the majority of the policies in our sample address the regulative and/or the cultural/cognitive pillar. This was illustrated by policies designed to prevent overt forms of discrimination against women in general as well as women entrepreneurs specifically. In other instance, policies and policy actions targeted the skills and attitudes of women entrepreneurs (cultural/cognitive). Examples of these include the development of women's business centers that provide a combination of training, mentoring, and networking with key resource providers.

In contrast, however, policies that addressed the normative pillar (values, expectations, standards, and conventions) were less prominently featured. The normative pillar encompasses the broader ecosystem and environment in which women entrepreneurs operate. The gender barriers discussed earlier in this paper suggest that women entrepreneurs, in spite of their growing numbers and contributions, are still not valued and recognized as an integral part of the entrepreneurial ecosystem and environment. This weakness in the normative pillar, in particular, highlights the need for an entrepreneurial ecosystem that encompasses and embraces women entrepreneurs as well as public policies that address normative as well as regulative and cultural/cognitive factors.

\section{Limitations}

While the Global WEP Research project has facilitated one of the few cross-country comparative studies about women's entrepreneurship policy, the authors acknowledge the limitations of the study. Personal bias and preference may have subconsciously influenced the identification and selection of text documents and programs/initiatives submitted for 
examination. Subjective biases - inherent in all content/narrative analysis - may have created minor discrepancies in the interpretation of data. Incomplete data sets due to missing information, such as gender make-up of author teams, limit the extent of our analysis. Such limitations can be reviewed and potentially addressed in Phase II of the project.

\section{Future research: next steps}

Findings from Phase I of the Global WEP Research project suggest several avenues for future research. First, there is a need for a larger sample of policy documents, including texts from Asia and South America. These two regions remain under-researched. This will facilitate more robust comparison of policies among economies at differences stages of development, within different regulatory regimes, and situated in different normative and cognitive conditions. Second, there is need to further explore gender influences of authorship (of policy documents) on policy design and implementation, especially with respect to the nature and quality of women-focused entrepreneurship policies, the extent to which policies address particular gender barriers, and the potential influence of the regulatory, normative or cognitive environment. Finally, future research will benefit from delving deeper into why there appears to be a significant disconnect between formal women's entrepreneurship policy and operational business support services (practices 'on the ground'). More importantly, the research team wondered if and why there is reluctance to close policy and program gaps.

\section{Acknowledgements}

The authors are grateful to Enterprise Ireland for hosting the first Global WEP Workshop in Dundalk, Ireland, in October 2015.

This paper is an earlier version of the following book chapter: Women's entrepreneurship policy: A 13-nation cross country comparison, Colette Henry, Barbara Orser, Susan Coleman, Lene Foss and Friederike Welter, in Manolova, Tatiana S., Brush, Candida G. Edelman, Linda F. and Welter, Friederike (ed.) (2017), Entrepreneurial Ecosystems and Growth of Women's Entrepreneurship, Cheltenham, UK and Northampton, MA, USA: Edward Elgar Publishing. We are grateful to Edward Elgar Publishing for granting permission to reprint this chapter in the International Journal of Gender and Entrepreneurship (IJGE).

\section{REFERENCES}

Acs, A., Szerb, L. and Autio, E. (2014). Gender Global Development Index. Accessed at: http://thegedi.org/global-entrepreneurship-and-development-index/ Acs, Z. and Virgill, N. (2011). Entrepreneurship in Developing Countries. Handbook of Entrepreneurship Research. International Handbook Series on Entrepreneurship (Eds. Z. Acs \& D. Audretsch). Springer Science+Business Media, p. 485-515. 
Ahl, H. (2004). The Scientific Reproduction of Gender Inequality, CBS Press, Copenhagen.

Ahl, H. (2006). Why Research on Women Needs New Directions, Entrepreneurship Theory and Practice, 30 (5): 595-621.

Ahl, H. and Nelson, T. (2014). How policy positions women entrepreneurs : A Comparative analysis of state discourse in Sweden and the United States, Journal of Business Venturing, 30: 273-291.

Ahmad, N. and Hoffman, A. (2007). A Framework for Addressing and Measuring Entrepreneurship. Paris: OECD Entrepreneurship Indicators Steering Group, November 20, 2007), 4, accessed at http://www.oecd.org/industry/business-stats/39629644.pdf.

Aldrich, H. E. (1989). Networking Among Women Entrepreneurs. In Women-Owned Businesses edited by O. Hagan, C. Rivchun, and D. Sexton. New York: Praeger, pp103-32.

Aldrich, H. E., Reese, P.R. and Dubini, P. (1989). Women on the Verge of a Breakthrough: Networking Among Entrepreneurs in the United States and Italy. Entrepreneurship and Regional Development 1 (4), 339-356.

APEC (2004). 2nd OECD Conference of Minsters Responsible for Small and Medium-sized Enterprises (SEMs) Promoting Entrepreneurship and Innovative SMEs in a Global Economic. Towards More Responsible and Inclusive Globalization. Istanbul, Turkey 3-5 June 2004.

APEC (2010). Decloration. The APEC Women's Entrepreneurship Summit October 1, 2010 in Gifu, Japan.

APEC (2011). Declaration. High Level Policy Dialogue on Women and the Economy. San Francisco, California, September 16,2011.

Arulampalam, Wiji, Alison L. Booth, and Mark L. Bryan (2007). Is There A Glass Ceiling over Europe/ Exploring the Gender Pay Gap Across the Wage Distribution. Industrial and Labor Relations Review 60 (2), 163-186.

Berglund, K. and Granat Thorslund, J. (2010). A policy to unleash innovation: How can gender improve innovation and entrepreneurship policy? Triple Helix VIII International Conference on University, Industry and Government Linkages, 20-22 October, Madrid.

Birley, S. (1989). Female Entrepreneurs: Are They Really Any Different? Journal of Small Business Management 27 (1), 32-37.

Blau, F. D. and Kahn, L.M. (2007). The Gender Pay Gap: Have Women Gone as Far as They Can? Academy of Management Perspectives 21, 7-23.

Brush, Candida, Nancy Carter, Elizabeth Gatewood, Patricia Greene, and Myra Hart (2001a). The Diana Project: Women Business Owners and Equity Capital: The Myths Dispelled. Kansas City, Missouri: Kauffman Center for Entrepreneurial Leadership.

Brush, C.G., Greene, P.G., \& Hart, M.M. (2001b). From Initial Idea to Unique Advantage: The Entrepreneurial Challenge of Constructing a Resource Based. Academy of Management Executive 15 (1), 64-78.

Brush, Candida, Nancy Carter, Elizabeth Gatewood, Patricia Greene, and Myra Hart (2004). 
Gatekeepers of Venture Growth: A Diana Project Report on the Role and Participation of Women in the Venture Capital Industry. Kansas City, Missouri: Kauffman Center for Entrepreneurial Leadership.

Brush, Candida G., Nancy M. Carter, Patricia G. Greene, Myra M. Hart and Elizabeth Gatewood (2002). The Role of Social Capital and Gender in Linking Financial Suppliers and Entrepreneurial Firms: A Framework for Future Research. Venture Capital 4 (4), 305-323.

Brush, Candida G., Anne de Bruin, and Friederike Welter (2009). A gender-aware framework for women's entrepreneurship. International Journal of Gender and Entrepreneurship 1 (1), 8-24.

Canadian Taskforce for Women's Business Growth (2011). Action Strategies to Support Canadian Women-Owned Enterprises, University of Ottawa Telfer School of Management, Ottawa, Accessed at: http://sites.telfer.uottawa.ca/womensenterprise.

Catalyst (2016) Pyramid: Women in S\&P Companies. New York: Catalyst, February 3.

Cliff, J. E. (1998). Does One Size Fit All? Exploring the Relationship Between Attitudes Toward Growth, Gender and Business Size. Journal of Business Venturing 13, 523-542.

Closing the Gender Gap: Act Now (2012). OECD Publishing. Retrieved at http://dx.doi.org/10.1787/9789264179370-en on 4/16/16.

Coleman, S. (2007). The Role of Human and Financial Capital in the Profitability and Growth of Women-Owned Small Firms. Journal of Small Business Management 45 (3), 303-319.

Coleman, S. and Robb, A.M. (2012). A Rising Tide: Financing Strategies for Women-Owned Firms. Stanford, California: Stanford University Press.

Coleman, S. and Robb, A.M. (2016). Financing High-Growth Women-Owned Enterprises: Evidence from the United States. In Women's Entrepreneurship in Global and Local Contexts edited by Maria Diaz-Garcia, Candida G. Brush, Elizabeth G. Gatewood, and Frederike Welter. Edward Elgar: Cheltenham, UK.

Du Rietz, A. and M. Henrekson (2000). Testing the Female Underperformance Hypothesis. Small Business Economics, 14, 1-10.

European Union (EU) Enterprise and Industry (2008). Evaluation on Policy: Promotion of Women Innovators and Entrepreneurship. Accessed on April 10, 2016 at file:///Users/barbaraorser/Downloads/women_innovators_and_entrepreneurship_3815.pdf European Commission (2004). Promoting entrepreneurship amongst women, Best Reports No. 2, European Commission: Enterprise Publications, Enterprise Directorate-General, also see Finnegan, G. (2003), Are W.E. being served? -The work of the International Labour Organization (ILO) in promoting more and better BDS for women entrepreneurs. Paper presented at the ILO's BDS Seminar, Turin, Italy, September 11, 2004.

Fischer, E. M., Reuber, A. R. and Dyke, L. S. (1993). A theoretical overview and extension of research on sex, gender, and entrepreneurship. Journal of business venturing, 8(2), 151-168. 
Foss, L., Henry, C. and Ahl, H. (2014) A review of Policy and Practice Implications in Gender and Entrepreneurship Research, Diana International Research Conference, Stockholm, June $15-17^{\text {th }}$.

Foss, L. and Gibson, D. (Eds.) (2015). The Entrepreneurial University. Context and Institutional Change, Routledge, New York.

Garcia, M. C. and Carter, S. (2009). Resource Mobilization Through Business Owners' Networks: Is Gender an Issue? International Journal of Gender and Entrepreneurship 1 (3), 226-252.

Global Entrepreneurship Development Institute (2015). Female Entrepreneurship Index. Accessed on April 10, 2016 at https://thegedi.org/research/womens-entrepreneurship-index/

Global Entrepreneurship Monitor (GEM, 2016). 2015/2016 Global Report. Accessed on April 10, 2016 at file:///Users/barbaraorser/Downloads/gem-2015-2016-global-report-1104161460370041.pdf

Global Entrepreneurship Monitor (2014) Women's Report. Accessed April 10, 2016 at: http://gemconsortium.org/report/49281

Global Women Entrepreneur Leaders (GWEL) Scorecard (2015). Accessed on April 10, 2016 at https://www.dell.com/learn/us/en/vn/corporate secure en/documents 2015-gwel-countrycategory-scores.pdf

Griffiths, M., Gundry, L. and Kickul, J. (2013). Journal of Small Business and Enterprise Development, 20(2): 341-357.

Hanlon, D. and Saunders, C. (2007). Marshaling Resources to Form Small New Ventures: Toward a More Holistic Understanding of Entrepreneurial Support. Entrepreneurship Theory and Practice, 31(4): 619-641.

Hart, D. (2003). Entrepreneurship policy: What it is and where it came from? The emergence of entrepreneurship policy. Governance, start-ups and growth in the US knowledge economy, 319.

Haynes, George W. and Deborah C. Haynes (1999). The Debt Structure of Small Businesses Owned by Women in 1987 and 1993. Journal of Small Business Management 37 (2), 1-19.

Henry, C., Foss, L. \& Ahl, H. (2016), Gender and entrepreneurship research: A review of methodological approaches. International Small Business Journal. 34(3): 217-241.

Kvidal, T. and Ljunggren, E. (2014). Introducing gender in a policy program: a multilevel analysis of an innovation policy program. Environment and Planning C: Government and Policy, 32(1), $39-53$.

Lundstrom, A. and Stevenson, L. (2002). On the Road to Entrepreneurship Policy, Entrepreneurship Policy for the Future Series, Vol. 1, Swedish Foundation for Small Business Research, Örebro University, Örebro.

Ljunggren, E. and Alsos, G.A. (2012). Gender and Innovation- Towards a Research Framework. Working paper, Nordland Research Institute, Norway. 
Marlow, S. and McAdam, M. (2013, August). Incubation or Induction? Gendered Identify Work in the Context of Technology Business Incubation. Entrepreneurship Theory and Practice, 1-26.

Marlow, S., Carter, S. and Shaw, E. (2008). Constructing female entrepreneurship policy in the UK: is the US a relevant benchmark? Environment and Planning C: Government and Policy, 26(2), $335-351$.

Mason, C. and Brown, R. (2014). Entrepreneurial Ecosystems and Growth-Oriented Entrepreneurship. Final Report to OECD. Paris. http://www.oecd. org/cfe/leed/Entrepreneurial-ecosystems.pdf.

Mayoux, L. (2001). Jobs, gender and small enterprises: getting the policy environment right (No. 346709). International Labour Organization.

Mazzarol, T. (2014) "Small business diagnostic: what does it tell us about SMEs?" CEMI Discussion Paper Series, DP 1402, Centre for Entrepreneurial Management and Innovation, www.cemi.com.au

Mayoux, L. (2001). Jobs, Gender and Small Enterprises: Getting the Policy Environment Right, Infocus Program on Boosting Employment Through Enterprise Development, Job Creation and Enterprise Development, International Labour Office (ILO), Geneva.

Minniti, M. and Nardone, C. (2007). Being in Someone Else's Shoes: the Role of Gender in Nascent Entrepreneurship. Small Business Economics, 28: 223-238.

OECD (2014). Enhancing Women's Economic Empowerment through Entrepreneurship and Business Leadership in OECD Countries. Accessed April 11, 2016 at http://www.oecd.org/gender/Enhancing\%20Women\%20Economic\%20Empowerment_Fin_1_ Oct_2014.pdf

Orser, B. and Elliott, C. (2015). Feminine Capital. Unlocking the Power of Women Entrepreneurs. Stanford University Press, Redwood, California.

Orser, B. (2011) Canadian Taskforce for Women's Business Growth. Accessed April 30, 2016 at http://sites.telfer.uottawa.ca/womensenterprise/

Orser, B. and Riding, A. (2006). Gender-based Small Business Programming: The Case of the Women's Enterprise Initiative. Journal of Small Business and Entrepreneurship, 19(2): 143166.

Piacentini, M. (2013). Women Entrepreneurs in the OECD: Key Evidence and Policy Challenges. OECD Social Employment and Migration Working Papers, No. 147, OECD Publishing. Retrieved at http://dx.doi.org/10.1787/5k43bvtkmb8v-edn on 4/20/16.

Ranga, M. and Etzkowitz, H. (2010). Athena in the World of Techne: The Gender Dimension of Technology, Innovation, and Entrepreneurship. Journal of Technology Management and Innovation 5(1), 1-12.

Rankin, L.P. and Vickers, J. (2001). Women's Movements and State Feminism: Integrating Diversity into Public Policy. Ottawa: Status of Women Canada.

Schramm, C. J. (2004). Building Entrepreneurial Economies, Foreign Affairs 83(4), 104-115. 
Scott, W. R (2014). Institutions and organizations: Ideas, interests and identities. $4^{\text {th }}$ edition.

Thousands Oaks, CA. Sage

Sirmon, D.G. and Hitt, M.A. (2003, Summer). Managing Resources: Linking Unique Resources, Management, and Wealth Creation in Family Firms. Entrepreneurship Theory and Practice, 339-358.

Stam, E. (2015). Entrepreneurial ecosystems and regional policy: a sympathetic critique. European Planning Studies, 23(9), 1759-1769.

Stevenson, H. (2004). Intellectual foundations of entrepreneurship. Entrepreneurship: The Way Ahead. New York: Routledge: 3-14.

Tolbert, P.S., David, R.J. and Sine, W.D. (2011) Studying choice and change: The intersection of institutional theory and entrepreneurship research. Organization Science, 22 (5), 1332-1344.

The Economist (2012). Women's economic opportunity, 2012. Economist Intelligence Unit, Women's Enterprise Scotland, Scotland (2015).

Women in Enterprise. A Framework and Action Plan to Increase the Contribution of Women's Enterprise to the Scottish Economy.

Women in the Labor Force (2015, December). U.S. Bureau of Labor Statistics, Report 1059. Retrieved at http://www.bls.gov.

World Bank Group (2014). Supporting Growth- oriented Women: Entrepreneurs: A review of the Evidence and Key Challenges. Innovation, Technology \& Entrepreneurship Policy Note, No. 5, www.worldbank.org.

Welter, F. and Smallbone, D. (2011). Institutional perspectives on entrepreneurial behavior in challenging environments. Journal of Small Business Management, 49(1), 107-125.

Zapalska, A. (1997). A profile of woman entrepreneurs and enterprises in Poland. Journal of Small Business Management, 35(4), 76. 
Table 1. Reading guide

Document Category (i.e. 1, 2, 3, 4):

1. Publication/Document Title

2. Author names/Issuing Authority

3. Gender breakdown of authors (where applicable)

4. Year of Publication

5. Sponsored by (where applicable)

6. Focus:

(i.e. is the document focused specifically on female entrepreneurship or entrepreneurship in general?

Does the document refer to a particular stage of development, growth, strategy, region, age or sector?)

7. Content Analysis:

7a. Dominant imagery used on cover of document (i.e. is it predominantly male or female? Is the imagery used gendered?)

7b. Types of imagery and language used throughout the document

7c. Key themes covered (entrepreneurship, technology/manufacturing, internationalization, etc.)

7d. Definitions used of key terms

8. Brief summary of main recommendations

9. Level of relevance to female entrepreneurship specifically

10. Does the reader note any evidence of gender bias?

11. Key contribution to Women's Enterprise Policy in the relevant country

12. Any other comments 
Table 2. Snippet samples of the data collected

\begin{tabular}{|c|c|c|c|c|c|c|c|c|}
\hline $\begin{array}{l}\text { Sample/ } \\
\text { Country }\end{array}$ & $\begin{array}{l}\text { Document Title/ } \\
\text { Category }\end{array}$ & $\begin{array}{l}\text { Author } \\
\text { Gender }\end{array}$ & $\begin{array}{l}\text { General/ } \\
\text { Women } \\
\text { Focused } \\
\end{array}$ & $\begin{array}{l}\text { Focus/ } \\
\text { Themes }\end{array}$ & $\begin{array}{l}\text { Dominant } \\
\text { Imagery/ } \\
\text { Language }\end{array}$ & Recommendations & $\begin{array}{l}\text { Level of } \\
\text { relevance }\end{array}$ & Key Contribution \\
\hline Canada & $\begin{array}{l}\text { Action strategies } \\
\text { to promote } \\
\text { women's } \\
\text { enterprise } \\
\text { development (3) }\end{array}$ & $\begin{array}{l}\text { All } \\
\text { female }\end{array}$ & $\begin{array}{l}\text { Women } \\
\text { focused }\end{array}$ & $\begin{array}{l}\text { Policies and } \\
\text { programs to } \\
\text { support } \\
\text { women's } \\
\text { e/pship and } \\
\text { growth }\end{array}$ & $\begin{array}{l}\text { Gender neutral; } \\
\text { pie charts, } \\
\text { graphs, national } \\
\text { symbols }\end{array}$ & $\begin{array}{l}\text { Need to establish a national strategy to } \\
\text { support the growth of women-owned } \\
\text { firms; better co-ordination of existing } \\
\text { policies; increase access to capital; support } \\
\text { to increase digital technology adoption; } \\
\text { help women business owners to develop } \\
\text { new markets; enhance financial literacy }\end{array}$ & High & $\begin{array}{l}\text { Represents a collective } \\
\text { and political roadmap to } \\
\text { support women's } \\
\text { enterprise and growth }\end{array}$ \\
\hline Germany & $\begin{array}{l}\text { Women } \\
\text { entrepreneurs- } \\
\text { fostering female } \\
\text { e/pship in } \\
\text { Germany (2) }\end{array}$ & $\begin{array}{l}\text { Not } \\
\text { listed }\end{array}$ & $\begin{array}{l}\text { Women } \\
\text { focused }\end{array}$ & $\begin{array}{l}\text { Female e/pship } \\
\text { without specific } \\
\text { restriction to a } \\
\text { particular stage } \\
\text { of development }\end{array}$ & $\begin{array}{l}\text { Neutral cover, } \\
\text { but 'Frauen' } \\
\text { (women') } \\
\text { highlighted in } \\
\text { title. Language: } \\
\text { focused on } \\
\text { women. }\end{array}$ & $\begin{array}{l}\text { No specific recommendations, rather, this } \\
\text { is a strategy document outlining initiatives } \\
\text { to be implemented in relation to: } \\
\text { enhancing women entrepreneurs' image; } \\
\text { advisory services and networks; financing; } \\
\text { combining family and e/pship. }\end{array}$ & High & $\begin{array}{l}\text { This is the first } \\
\text { government paper to } \\
\text { spell out a joint strategy } \\
\text { to foster women } \\
\text { entrepreneurs. }\end{array}$ \\
\hline Sweden & $\begin{array}{l}\text { Promoting } \\
\text { women's e/pship } \\
(2)\end{array}$ & $\begin{array}{l}\text { Not } \\
\text { listed }\end{array}$ & $\begin{array}{l}\text { Women } \\
\text { focused }\end{array}$ & $\begin{array}{l}\text { Female e/pship; } \\
\text { creating more } \\
\text { female } \\
\text { entrepreneurs } \\
\text { and helping } \\
\text { them grow }\end{array}$ & $\begin{array}{l}\text { Lots of pictures } \\
\text { of women in } \\
\text { different roles - } \\
\text { some are } \\
\text { gendered. } \\
\text { Language: } \\
\text { politically } \\
\text { correct. }\end{array}$ & $\begin{array}{l}\text { Promote more women-owned businesses } \\
\text { and help them grow by providing: business } \\
\text { development, counselling \& mentoring } \\
\text { programs; business transfer initiatives; } \\
\text { business angel networks; gender training } \\
\text { of business advisors; role model programs; } \\
\text { business competitions; special focus on } \\
\text { green, cultural, health \& education sectors. }\end{array}$ & High & $\begin{array}{l}\text { This is the government's } \\
\text { policy on women's } \\
\text { e/pship. }\end{array}$ \\
\hline Tanzania & $\begin{array}{l}\text { The United } \\
\text { Republic of } \\
\text { Tanzania (URT): } \\
\text { Small and } \\
\text { medium } \\
\text { enterprise } \\
\text { development } \\
\text { policy (2) }\end{array}$ & $\begin{array}{l}\text { Not } \\
\text { listed }\end{array}$ & General & $\begin{array}{l}\text { SME } \\
\text { development; } \\
\text { includes a } \\
\text { section on } \\
\text { entrepreneurship } \\
\text {-gender and } \\
\text { disadvantaged } \\
\text { groups. Focus } \\
\text { on international } \\
\text { markets. }\end{array}$ & Neutral & $\begin{array}{l}\text { Support the establishment of SME } \\
\text { associations; establish forum for SMEs; } \\
\text { facilitate strengthening of service } \\
\text { providers for SMEs; strengthen } \\
\text { government capacity to coordinate, } \\
\text { monitor and evaluate policy; enhance } \\
\text { knowledge and skills of govern officials } \\
\text { involved in SME development }\end{array}$ & Medium & $\begin{array}{l}\text { Contributes very little to } \\
\text { women's } \\
\text { entrepreneurship policy } \\
\text { - only a small section in } \\
\text { the document. }\end{array}$ \\
\hline
\end{tabular}


Table 3. Summary of key observables from the data collected

\begin{tabular}{|c|c|}
\hline Countries & $\begin{array}{l}\mathrm{N}=13 \text { : Australia, Canada, Germany, Ireland, New Zealand, Northern Ireland, Pakistan, Spain, Sweden, UK, USA, Norway, } \\
\text { Tanzania. }\end{array}$ \\
\hline Document categories & $\begin{array}{l}37 \text { x category } 2 \text { documents }- \text { i.e. government issued and/or government contracted policy documents } \\
1 \text { x category } 3 \text { documents }- \text { i.e. reports/studies produced by other organizations. }\end{array}$ \\
\hline $\begin{array}{l}\text { General entrepreneurship or women- } \\
\text { specific focus }\end{array}$ & $\begin{array}{l}20 \mathrm{x} \text { general entrepreneurship documents } \\
18 \mathrm{x} \text { women focused documents }\end{array}$ \\
\hline Gender breakdown of authors & $\begin{array}{l}\text { All women }=3 \text { (one document each from Canada, Northern Ireland and USA); All men }=2 \\
\text { Women/Men mix }=7 ; \text { Unknown }(?)=26 \text { (i.e. 'authored by' the government or an institution) }\end{array}$ \\
\hline Dominant imagery & $\begin{array}{l}\text { No imagery or neutral/generic imagery }=21 \\
\text { Women-focused imagery }=7 \\
\text { No commentary made on imagery by the research team }=10\end{array}$ \\
\hline Dominant language & $\begin{array}{l}\text { Neutral/generic language }=18 ; \text { Female-focused }=7 \\
\text { Male focused }=3 ; \text { No commentary made on language by the research team }=10\end{array}$ \\
\hline Areas of focus & $\begin{array}{l}\text { Growth; resources (mainly finance); internationalization; competitiveness; barriers; specific sectors - e.g., youth, rural, agri- } \\
\text { business, STEM, ICT, craft; developing the eco-system (right conditions, improving rules and bureaucracy). }\end{array}$ \\
\hline Recommendations & $\begin{array}{l}\text { Education in financial literacy; increasing soft supports; encouraging growth of STEM; improving co-ordination amongst } \\
\text { policies and agencies; target specific sectors; improve welfare benefits for entrepreneurs; empower youth. }\end{array}$ \\
\hline $\begin{array}{l}\text { Level of relevance to women's } \\
\text { entrepreneurship }\end{array}$ & High (includes 'med-high' descriptions) $=17 ; \mathrm{Med}=7 ;$ Low $=6 ;$ None $=5 ;$ Not commented on $=3$ \\
\hline $\begin{array}{l}\text { Key contribution to women's } \\
\text { entrepreneurship policy }\end{array}$ & $\begin{array}{l}\text { Varied; confirm prior research; identify gaps in provision; highlight differences/challenges/barriers; articulates/reaffirms } \\
\text { government's commitment to women's entrepreneurship; paves the way for women-focused initiatives; enhances women's } \\
\text { welfare rights; highlights women in healthcare and STEM; highlights need for a dedicated policy; perpetuates gendered } \\
\text { myths. }\end{array}$ \\
\hline
\end{tabular}


Table 4. Preliminary overview of categories of notable initiatives 'on the ground'

\begin{tabular}{|c|c|c|c|c|c|}
\hline Country & Education & Experience & Networks & Access to Capital & Context \\
\hline Australia & $\begin{array}{l}\text { Financial } \\
\text { Literacy } \\
\text { program }\end{array}$ & $\begin{array}{l}\text { Business } \\
\text { management advice } \\
\text { \& capability } \\
\text { programs }\end{array}$ & $\begin{array}{l}\text { Innovation } \\
\text { Connections }\end{array}$ & & \\
\hline Canada & & $\begin{array}{l}\text { Women's Business } \\
\text { Centres. }\end{array}$ & $\begin{array}{l}\text { Networks; } \\
\text { Associations }\end{array}$ & Micro loans & $\begin{array}{l}\text { Women's Business } \\
\text { Centres. }\end{array}$ \\
\hline Germany & & $\begin{array}{l}\text { National Co- } \\
\text { ordination Office for } \\
\text { Women } \\
\text { Entrepreneurs }\end{array}$ & Networks & $\begin{array}{l}\text { Various financial } \\
\text { initiatives }\end{array}$ & $\begin{array}{l}\text { National Co-ordination } \\
\text { Office for Women } \\
\text { Entrepreneurs; Various } \\
\text { measures to reintegrate } \\
\text { women into employment; } \\
\text { Project "FRAUEN } \\
\text { unternehmen" addressing } \\
\text { need for visibility of } \\
\text { women entrepreneurs }\end{array}$ \\
\hline Ireland & & $\begin{array}{l}\text { Going for Growth } \\
\text { program }\end{array}$ & Networks & $\begin{array}{l}\text { Various financial } \\
\text { programs }\end{array}$ & \\
\hline $\begin{array}{l}\text { New } \\
\text { Zealand }\end{array}$ & & & & & $\begin{array}{l}\text { Māori Women's } \\
\text { Development Inc. } \\
\text { initiative. }\end{array}$ \\
\hline $\begin{array}{l}\text { Northern } \\
\text { Ireland }\end{array}$ & & $\begin{array}{l}\text { Various business } \\
\text { training and advice } \\
\text { programs }\end{array}$ & $\begin{array}{l}\text { Women in } \\
\text { Business } \\
\text { Network }\end{array}$ & & \\
\hline Norway & & Mentoring & Networks & $\begin{array}{l}\text { Competitive prize } \\
\text { funds }\end{array}$ & $\begin{array}{l}\text { Improving welfare benefits } \\
\text { for entrepreneurs }\end{array}$ \\
\hline Pakistan & $\begin{array}{l}\text { Women's } \\
\text { Study } \\
\text { Centres }\end{array}$ & $\begin{array}{l}\text { Skills Development } \\
\text { Centres; Reservation } \\
\text { of seats for women in } \\
\text { the National } \\
\text { Assembly. }\end{array}$ & & $\begin{array}{l}\text { The First Women } \\
\text { Bank Ltd }\end{array}$ & $\begin{array}{l}\text { Crisis Centres; Child care } \\
\text { Centres; Working } \\
\text { Women's Hostels }\end{array}$ \\
\hline Spain & & $\begin{array}{l}\text { Business Support } \\
\text { Program for Women } \\
\text { (PAEM); Program of } \\
\text { Development for } \\
\text { Women Potential } \\
\text { Managers. }\end{array}$ & & $\begin{array}{l}\text { Micro Credit } \\
\text { programs }\end{array}$ & \\
\hline Sweden & $\begin{array}{l}\text { Business } \\
\text { Ambassador } \\
\text { Program (in } \\
\text { schools) } \\
\end{array}$ & $\begin{array}{l}\text { Regional Resource } \\
\text { centres; Program } \\
\text { promoting women's } \\
\text { entrepreneurship. }\end{array}$ & Networks & & $\begin{array}{l}\text { Regional Resource Centres } \\
\text { (Established to create } \\
\text { gender equality) }\end{array}$ \\
\hline Tanzania & & $\begin{array}{l}\text { Women's } \\
\text { Entrepreneurship } \\
\text { Development Unit }\end{array}$ & $\begin{array}{l}\text { Tanzanian } \\
\text { Women } \\
\text { Chamber of } \\
\text { Commerce } \\
\text { (TWCC) } \\
\end{array}$ & $\begin{array}{l}\text { SERO - Business } \\
\text { Women's } \\
\text { association } \\
\text { involved in leasing } \\
\text { \& financing } \\
\end{array}$ & $\begin{array}{l}\text { Women Entrepreneurship } \\
\text { Development Unit (SIDO- } \\
\text { WED) }\end{array}$ \\
\hline$U K$ & & $\begin{array}{l}\text { Women's Business } \\
\text { Council (WBC) }\end{array}$ & & & $\begin{array}{l}\text { Women's Business } \\
\text { Council (WBC); } \\
\text { Mentoring programs - } \\
\text { 'Get Mentoring'/'Mentor- } \\
\text { me'. }\end{array}$ \\
\hline$U S A$ & & $\begin{array}{l}\text { Women's Business } \\
\text { Centres }\end{array}$ & & $\begin{array}{l}\text { 'InnovateHer' } \\
\text { program; 'JOBS' } \\
\text { funding initiative. }\end{array}$ & $\begin{array}{l}\text { Women's Business } \\
\text { Centres; Women's Equity } \\
\text { in Contracting Act; } \\
\text { Women-Owned Small } \\
\text { Business Contract Prog. }\end{array}$ \\
\hline
\end{tabular}




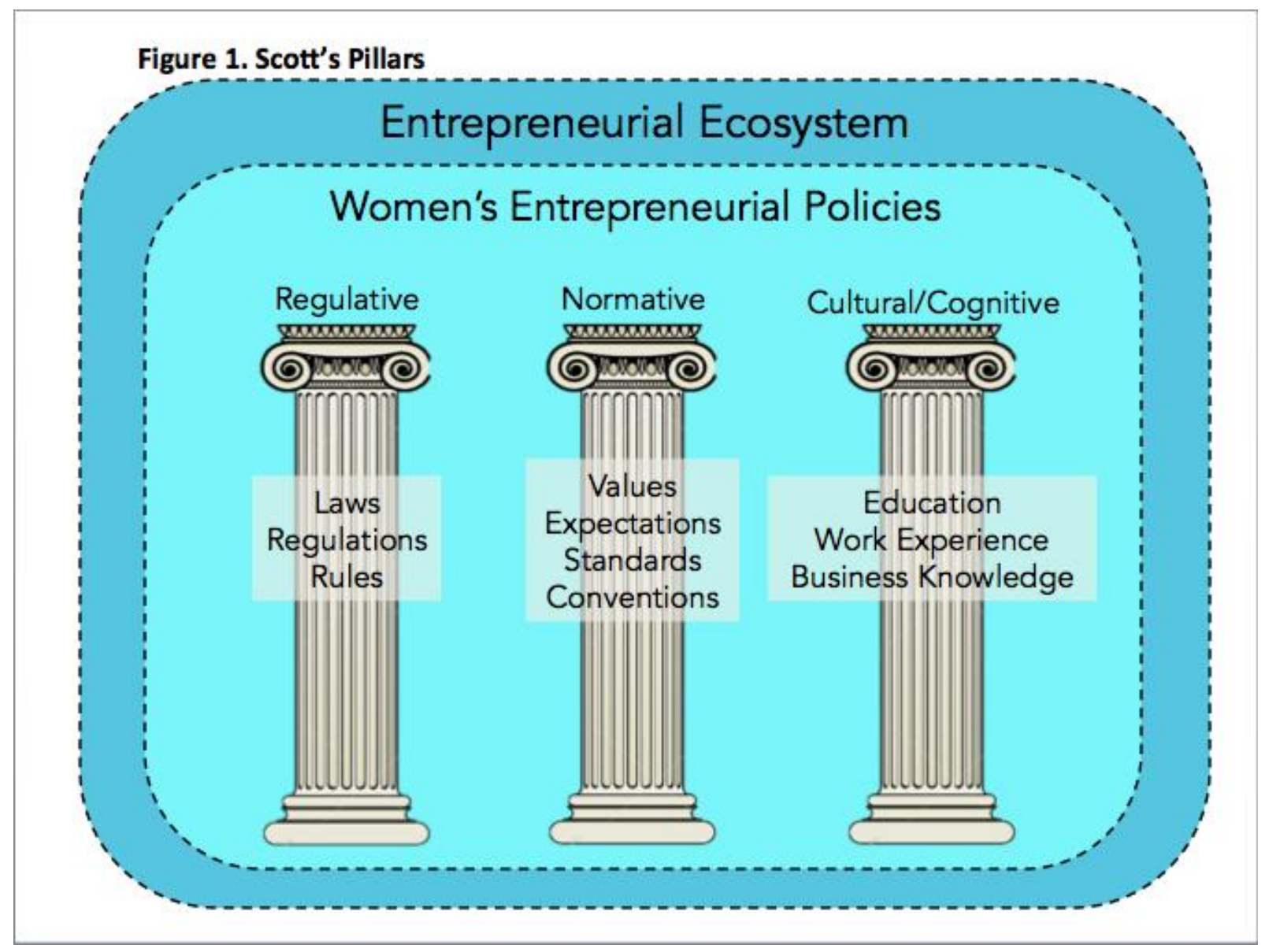

